\title{
Analisis kesalahan siswa dalam memecahkan masalah perbandingan berdasarkan langkah polya
}

\author{
Humayatun Faseha ${ }^{1}$, Erpin $_{\text {Evendi }}{ }^{2}$, Yandika Nugraha ${ }^{3} *$ \\ *Affiliasi: Universitas Islam Negeri Mataram
}

Kata kunci :

kesalahan, langkah polya, pemecahan masalah, perbandingan

\begin{abstract}
Abstrak
Penelitian ini bertujuan untuk mendeskripsikan jenis kesalahan siswa dalam memecahkan masalah perbandingan dengan menggunakan bantuan pemecahan masalah berdasarkan langkah polya. Dengan pendekatan penelitian penelitian jenis studi kasus. Subjek penelitian dipilih mengggunakan sampel bertujuan (purposive simple), dipilih 3 subjek penelitian, siswa dipilih dengan pertimbangan bahwa siswa tersebut mempunyai kemampuan mengemukakan pendapat baik secara lisan dan tertulis serta kemampuan matematika yang memenuhi kriteria sebagai subjek penelitian yakni tinggi, sedang dan rendah. Proses pengumpulan data dengan metode interview dengan teknik think aloud method, yaitu siswa diminta untuk mengungkapkan ekspresi verbal tentang ide yang dipikirkan ketika menyelesaikan masalah perbandingan. Sedangkan analisis data adalah reduksi data, penyajian data, dan menarik kesimpulan. Hasil penelitian ini menunjukan bahwa terdapat jenis kesalahan siswa dalam memecahkan masalah perbandingan berdasarkan langkah polya. Pada langkah memahami masalah, jenis kesalahan siswa adalah siswa tidak dapat mengungkapkan apa yang diketahui dan yang ditanyakan, siswa tidak dapat membedakan perbandingan senilai dan berbalik nilai; langkah merencanakan masalah, siswa tidak dapat merencanakan masalah sesuai dengan informasi yang ada dalam soal; langkah melaksanakan rencana pemecahan masalah, siswa tidak dapat menghitung dengan perhitungan yang tepat; langkah memeriksa kembali solusi yang di peroleh siswa tidak memeriksa kembali solusi yang diperoleh karena yakin dengan jawabannya.
\end{abstract}

\footnotetext{
${ }^{1}$ Corresponden to the author: Program Studi Tadris Matematika-FTK UIN Mataram, Jl. Gajah Mada Jempong, Indonesia. (83116), email address: faseha21@gmail.com

2 email address: erpin evendi@uinmataram.ac.id

3 email address: yandikanugraha@uinmataram.ac.id
}

Faseha, at.al (2021), Analisis kesalahan siswa dalam memecahkan masalah........| 40-54 | 
Keywords:

errors, pattern steps, problem solving, comparison.

\section{A b s tract}

This study aims to describe the types of errors of students in solving comparative problems using problem solving assistance based on their pattern of steps. With a case study research research approach. Research subjects were selected using purposive simple sample, 3 research subjects were selected, students were selected with the consideration that these students had the ability to express opinions both orally and in writing as well as mathematical abilities that met the criteria as research subjects, namely high, medium and low. The process of collecting data using the interview method with the think aloud method, in which students are asked to express verbal expressions about the ideas they think about when solving a comparison problem. While data analysis is data reduction, data presentation, and drawing conclusions. The results of this study indicate that there are types of student errors in solving comparison problems based on their pattern of steps. In the step of understanding the problem, the type of student error is that the student cannot express what is known and what is asked, the student cannot distinguish the comparison of values and reverses the value; steps to plan problems, students cannot plan problems according to the information in the questions; steps to carry out the problem-solving plan, students cannot calculate with the right calculation; the step of checking the solution obtained by students is not checking the solution obtained because they are sure of the answer.

\section{Pendahuluan}

Matematika merupakan sebuah ilmu dengan objek kajian yang bersifat abstrak. Sebagian besar yang dipelajari dalam matematika adalah angka atau bilangan yang secara nyata tidak ada atau merupakan hasil pemikiran otak manusia. Menurut Ruly (2010) sifat abstrak inilah yang menyebabkan terjadinya kesulitan ketika siswa menjawab soal. Kesulitan yang dialami siswa memungkinkan siswa melakukan kesalahan dalam memecahkan masalah matematika pada setiap pokok bahasan dalam pembelajaran. Salah satunya pada pokok bahasan perbandingan. Menurut Rahma, dkk (2015) perbandingan merupakan salah satu dasar untuk mempelajari matematika, sains dan berguna dalam dunia nyata serta berbagai situasi dalam kehidupan sehari-hari.

Selain contoh diatas, penggunaan perbandingan dalam kehidupan sehari-hari sering ditemukan. Contoh tersebut antara lain perbandingan jumlah barang yang dibeli dengan harga yang harus dibayar, perbandingan jumlah konsumsi bahan bakar dan jarak yang ditempuh, perbandingan jumlah kaleng cat dan luas permukaan yang bisa dicat, perbandingan banyaknya pekerja dengan waktu yang diperlukan untuk menyelesaikan pekerjaan dan sebagainya. Menurut Rahmawati, dkk (2016) walaupun sering ditemukan dalam kehidupan sehari hari masalah perbandingan tidaklah mudah. Banyak siswa yang melakukan kesalahan dalam memecahkan masalah perbandingan. Berdasarkan hasil observasi di MTs Nahdlatul Mujahidin NW Jempong menunjukan bahwa sebagian besar siswa melakukan kesalahan dalam memecahkan masalah perbandingan. Berdasarkan informasi dari siswa kelas VII, didapatkan hasil bahwa siswa tersebut sering mengalami kesulitan dalam

Faseha, at.al (2021), Analisis kesalahan siswa dalam memecahkan masalah........ 40-54| 
memecahkan masalah perbandingan, khususnya perbandingan senilai dan perbandingan berbalik nilai. Ada kemungkinan bahwa kesulitan yang dialami siswa dikarenakan siswa kurang mampu memahami soal dengan cermat sehingga informasi-informasi yang penting tidak digunakan dalam penyelesaian soal. Lebih lanjut lagi berdasarkan hasil wawancara dengan guru, hal tersebut terjadi karena kemampuan operasi aritmatika siswa serta kemampuan dalam memahami soal kurang sehingga siswa salah dan sulit membedakan perbandingan senilai dan berbalik nilai.

Mengingat begitu pentingnya masalah perbandingan dalam kehidupan, siswa diharapkan dapat memecahkan masalah perbandingan yang ditemukan dalam kehidupan mereka dan menggunakan langkah yang sistematis untuk menyelesaiakannya. Salah satunya pemecahan masalah berdasarkan langkah Polya. Menurut Polya (1973) terdapat empat langkah dalam memecahkan masalah yaitu memahami masalah, menyusun rencana, melaksanakan rencana dan mengecek kembali. Tahapan pemecahan masalah yang ditemukan oleh George Polya ini merupakan metode esensial untuk menyeleksi informasi yang relevan. Informasi tersebut berupa data dan permasalahan yang akan dicari penyelesaiannya. Peneliti menggunakan pemecahan masalah dengan menggunakan langkah Polya dalam penelitian ini karena langkah Polya menyediakan kerangka kerja yang tersusun rapi untuk menyelesaikan masaah. Beberapa hasil penelitian yang telah dilakukan sebelumnya menunjukan bahwa penyelesaian dengan menggunakan langkah Polya sangat efektif. Maka peneliti mencoba menggunakan langkah Polya untuk mengetahui jenis kesalahan yang dilakukan siswa dalam memecahkan masalah matematika pada pokok bahasan perbandingan.

George Polya, seorang matematikawan generalis berhasil menemukan seperangkat pertanyaan atau langkah-langkah untuk menyelesaikan masalah. Polya membuat metodemetode sistematis guna menemukan solusi atas problem-problem yang dihadapi dan memungkinkan seseorang menemukan pemecahannya sendiri karena memang sudah ada dan dapat dicari. Penelitian ini secara khusus akan membahas kesalahan-kesalahan siswa dalam menyelesaikan soal matematika dilihat dengan langkah-langkah Polya.

Empat langkah dalam memecahkan masalah matematika, yaitu sebagai berikut.

1. Memahami masalah (uderstanding problem)

"At this stage students must understand the given problem of determining what is known and what is asked to solve the given problem." Pada tahap ini siswa harus memahami masalah yang diberikan yaitu menentukan apa yang diketahui dan apa yang ditanyakan untuk menyelesaikan soal yang diberikan.

2. Merencanakan pemecahan masalah (devising a plan)

"At this stage students think very bright and good idea to plan what will be done to solve problem given, student able to determine strategy or method to be used and write down steps that will be used in solving problem." Pada tahap ini siswa memikirkan ide yang sangat cemerlang dan baik untuk merencanakan yang akan dilakukan untuk memecahkan masalah yang diberikan, siswa mampu menentukan strategi atau metode yang akan digunakan dan menuliskan langkahlangkah yang akan digunakan dalam menyelesaikan soal.

3. Melaksanakan rencana pemecahan masalah (carrying out the plan) 
"At this stage students undertake a plan that has been set at the planning stage of problem solving. The ability of students to understand the substance of the material and skills of students doing mathematical calculations will greatly help students to carry out the solution." Pada tahap ini siswa melakukan rencana yang telah ditetapkan pada tahap merencanakan pemecahan masalah. Kemampuan siswa memahami substansi materi dan keterampilan siswa melakukan perhitungan matematika akan sangat membantu siswa untuk melaksanakan penyelesaiannya.

4. Memeriksa kembali solusi yang diperoleh (looking back)

"At this stage students do the reflection of checking or testing solutions that have been obtained." Pada tahap ini siswa melakukan refleksi yaitu mengecek atau menguji solusi yang telah diperoleh.

Berdasarkan langkah-langkah pemecahan masalah Polya, pada penelitian ini indikator yang ingin diketahui oleh peneliti pada waktu siswa memecahkan masalah perbandingan dapat dilihat pada tabel berikut:

Tabel 1: Indikator Pemecahan Masalah Perbandingan Berdasarkan Langkah Polya

\begin{tabular}{|c|c|}
\hline Langkah Polya & Indikator \\
\hline $\begin{array}{l}\text { Memahami } \\
\text { masalah (understanding } \\
\text { problem) }\end{array}$ & $\begin{array}{l}\text { 1. Siswa dapat mengungkapkan apa yang } \\
\text { diketahui dan apa yang ditanyakan dari soal. } \\
\text { 2. Siswa mampu memahami apakah soal termasuk masalah perbandingan } \\
\text { senilai atau berbalik nilai. }\end{array}$ \\
\hline $\begin{array}{l}\text { Merencanakan } \\
\text { pemecahan masalah } \\
\text { (devising a plan) }\end{array}$ & $\begin{array}{l}\text { 1. Siswa mampu menyusun rencana sesuai dengan informasi yang ada dalam } \\
\text { soal } \\
\text { 2. Siswa mampu menyusun rencana pemecahan masalah dengan strategi } \\
\text { terlebih dahulu mencari pecahan senilainya kemudian melipatgandakan. } \\
\text { 3. Siswa mampu menyusun rencana pemecahan masalah dengan strategi } \\
\text { perhitungan menggunakan variabel dan memecahkan variabel tersebut } \\
\text { menggunakan aturan perkalian silang. }\end{array}$ \\
\hline $\begin{array}{l}\text { Melaksanakan } \\
\text { rencana pemecahan } \\
\text { masalah (carrying out } \\
\text { the plan) }\end{array}$ & $\begin{array}{l}\text { 1. Siswa mampu melaksanakan rencana pemecahan masalah dengan langkah- } \\
\text { langkah yang benar dan perhitungan yang tepat. }\end{array}$ \\
\hline $\begin{array}{l}\text { Memeriksa kembali } \\
\text { solusi yang diperoleh } \\
\text { (looking back) }\end{array}$ & $\begin{array}{l}\text { 1. Siswa mengidentifikasi kesalahan perhitungan. } \\
\text { 2. Siswa memeriksa kecocokan antara yang telah ditemukan dengan apa yang } \\
\text { ditanyakan. }\end{array}$ \\
\hline
\end{tabular}

\section{Metode}

Penelitian ini dilaksanakan di MTs Nahdlatul Mujahisin NW Jempong. Penelitian ini dapat digolongkan ke dalam jenis penelitian kualitatif studi kasus. Menurut Emzir (2010) penelitian studi kasus adalah suatu penelitian kualitatif yang berusaha menemukan makna, menyelidiki proses dan memperoleh pengertian dan pemahaman yang mendalam dari individu, kelompok atau situasi. Subjek dalam penelitian ini dipilih dari siswa kelas VII dengan pertimbangan: (1) Faseha, at.al (2021), Analisis kesalahan siswa dalam memecahkan masalah........ 40-54| 
telah mendapatkan pembelajaran mengenai perbandingan, (2) berdasarkan informasi dari guru matematika yang mengajar, siswa yang dapat mengkomunikasikan idenya dengan jelas baik secara tulisan maupun lisan, dan (3) mempunyai kemampuan awal matematika tinggi, sedang, dan rendah.

Data dalam penelitian ini dikumpulkan langsung oleh peneliti, sehingga instrumen utama penelitian yaitu peneliti sendiri sebagai pewawancara yang dibantu dengan instrumen bantu berupa soal tes pemecahan masalah perbandingan yang sebelumnya telah divalidasi oleh dua orang dosen ahli dan satu guru mata pelajaran. Teknik pengumpulan data dalam penelitian ini, yaitu menggunakan think aloud method, yaitu siswa diminta untuk mengungkapkan ekpresi verbal tentang ide yang dipikirkan ketika menyelesaikan soal perbandingan. Analisis data kualitatif yang peneliti gunakan pada penelitian ini adalah menggunakan model Miles and Huberman yaitu melalui tiga proses antara lain: reduksi data (data reduction), penyajian data (data display) dan penarikan kesimpulan (Conclusion Drawing)/verifikasi.

Untuk menjamin keabsahan data dan temuan, peneliti menggunakan triangulasi waktu dengan langkah-langkah sebagai berikut:

1. Peneliti mengambil data pemecahan masalah siswa dengan menggunakan think aloud method sebanyak dua kali dalam waktu yang berbeda.

2. Melakukan pengambilan data pertama.

3. Menganalisis hasil think aloud pada pengambilan data pertama.

4. Melakukan pengambilan data kedua.

5. Menganalisis hasil think aloud pada pengambilan data kedua.

6. Membandingkan hasil pengambilan data pertama dengan hasil pengambilan data kedua.

7. Apabila data hasil pertama dan kedua konsisten, maka data tersebut dinyatakan valid. Konsisten yang dimaksud yaitu pengumpulan data pertama dan data kedua memberikan hasil yang identik atau sama.

\section{Hasil dan Pembahasan}

Penentuan subjek dilakukan dengan terlebih dahulu berkonsultasi dengan guru matematika kelas VII MTs Nahdlatul Mujahidin NW Jempong untuk mendapatkan siswa yang sudah mendapat pembelajaran perbandingan. Berdasarkan hasil konsultasi dengan guru matematika bersangkutan, didapatkan siswa-siswa kelas VII yang sudah mendapatkan pembelajaran perbandingan dan sanggup dijadikan subjek penelitian. Berdasarkan pertimbangan dari guru matematika tentang kemampuan siswa dalam mengemukakan pendapat baik secara lisan maupun tertulis, serta kemampuan matematika siswa sehari-hari, maka selanjutnya dipilih siswa yang memenuhi kriteria sebagai subjek penelitian yaitu subjek $\mathrm{NK}, \mathrm{DMH}$ dan IA. 


\section{Pemecahan Masalah Berdasarkan Langkah Polya Subjek Kemampuan Tinggi}

1. Memahami Masalah

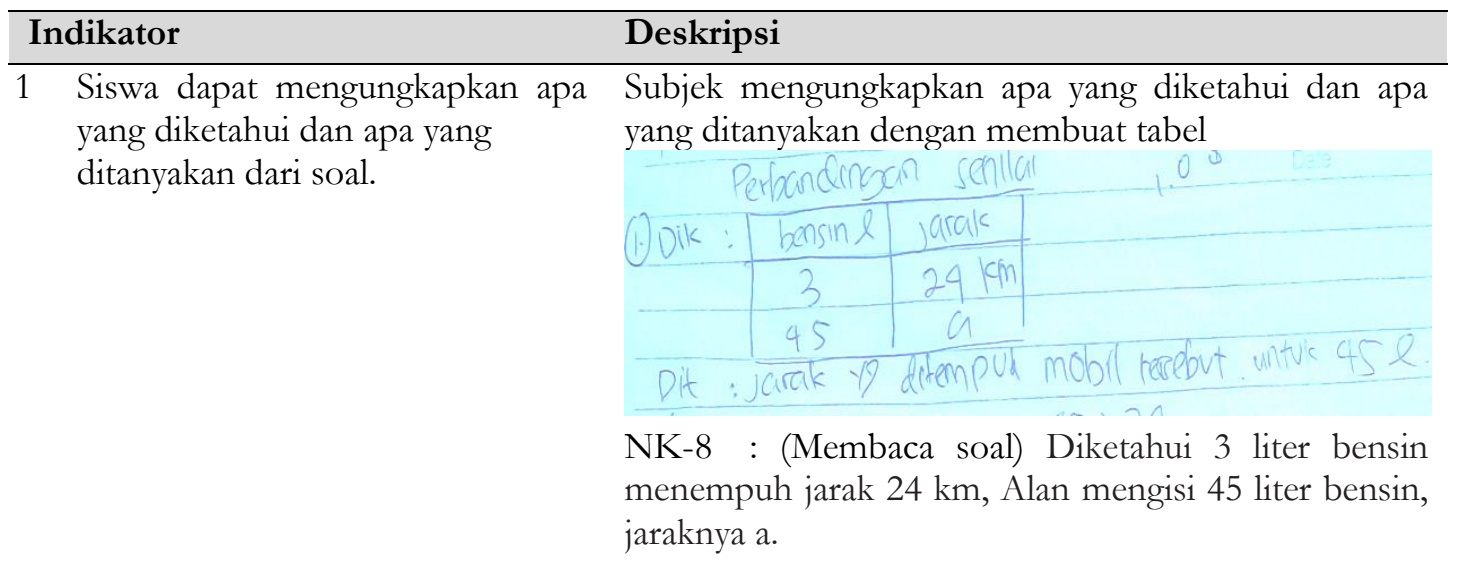

NK-12 : Ditanya jarak yang ditempuh mobil tersebut untuk 45 liter?

dan pada beberapa masalah Subjek meringkas soal dengan bahasa sendiri sehingga lebih mudah dalam memahami soal.

2 Siswa mampu memahami apakah soal termasuk masalah perbandingan senilai atau berbalik nilai

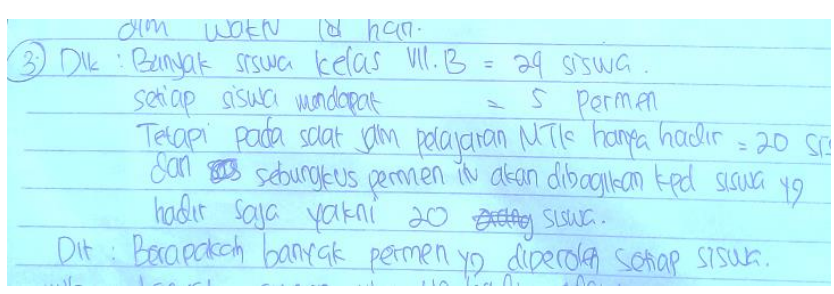

NK-36 : (Membaca Soal) Diketahui banyak siswa kelas VII B sama dengan 24 siswa, setiap siswa mendapat sama dengan 5 permen, tetapi pada saat jam pelajaran MTK hanya hadir sama dengan 20 siswa dan sebungkus permen itu akan dibagikan kepada siswa yang hadir saja yakni 20 siswa. Ditanya berapakah banyak permen yang diperoleh setiap siswa.

Subjek menjelaskan secara mendalam konsep perbandingan senilai dan berbalik nilai dengan sangat baik

P-19 : mmmm perbandingannya apa untuk soal no 1. (tes pertama)

NK-19 : Senilai Kak

P-20 : Darimana tahu kalok itu senilai?

NK-20 : Kan kalok bensinnya banyak jaraknya jauh, kalok kecil jaraknya deket

(Perbandingan berbalik nilai soal no 3) 
NK-44 : Perbandingan berbalik nilai karena makin sedikit siswa makin banyak permen yang didapat..

P-45 : Kalok siswanya banyak?

NK-45 : Makin sedikit Kak.

\section{Menyusun Rencana Pemecahan Masalah}

\section{Indikator}

1. Siswa mampu menyusun rencana sesuai dengan informasi yang ada dalam soal

\section{Deskripsi}

Subjek mampu menggali informasi yang tidak ada dalam soal. Sehingga Subjek mampu menyusun rencana dengan baik

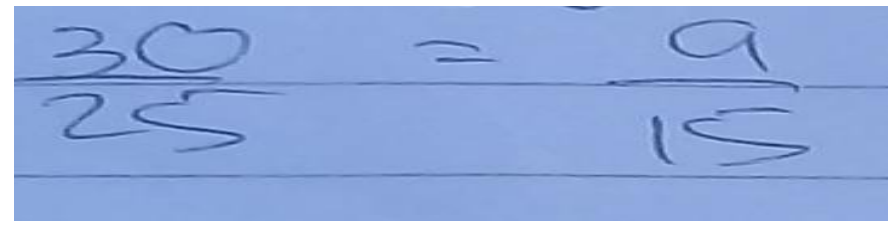

P-27 : Dari mana dapat 25?

NK-27 : Kan Pak Ahmad menjual 5 jadi 30-5

Subjek menyusun rencana pemecahan masalah rata-rata dengan menggunakan konsep perkalian silang

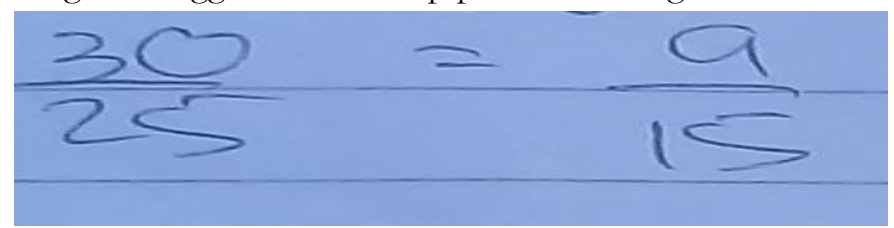

NK-28 $: \frac{30}{25}=\frac{a}{15}$, dikali silang, $25 \times a=30 \times a, a=$ $\frac{450}{25}, a=18$

dan beberapa soal dengan menggunakan strategi terlebih dahulu mencari pecahan senilai dan melipatgandakannya

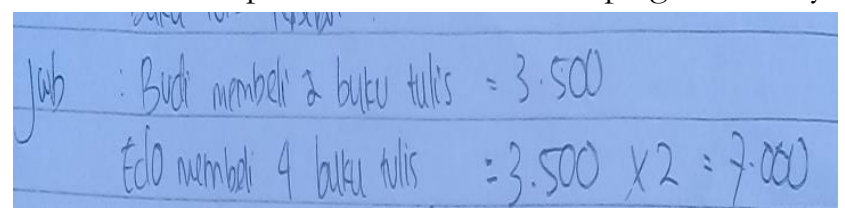




\section{Melaksanakan Rencana Pemecahan Masalah}

\begin{tabular}{|c|c|}
\hline Indikator & Deskripsi \\
\hline $\begin{array}{l}\text { 1. Siswa mampu } \\
\text { melaksanakan rencana } \\
\text { pemecahan masalah } \\
\text { dengan langkah-langkah } \\
\text { yang benar dan }\end{array}$ & $\begin{array}{l}\text { Subjek melaksanakan rencana pemecahan masalah dengan sangat } \\
\text { baik. Subjek melakukan perhitungan yang tepat karena } \\
\text { kemampuan aritmatika seperti perkalian, pembagian, } \\
\text { penjumlahan dan pengurangan sangat dikuasai. }\end{array}$ \\
\hline perhitungan yang tepat. & Jwh $\begin{aligned} & \frac{3}{45}=\frac{24}{a} \Rightarrow 3 \times a=45 \times 24 \\
& a=\frac{1.080}{3} \\
& a=360 \mathrm{~km} \\
& \text { jadi jarak } 49 \text { ditempun mobil tersebut untwk } 45 \mathrm{l} \\
& \text { a dalah } 360 \mathrm{~km} .\end{aligned}$ \\
\hline
\end{tabular}

\section{Memeriksa Kembali Solusi yang Diperoleh}

Indikator
$\begin{aligned} & \text { Siswa mengidentifikasi kesalah } \\ & \text { an perhitungan. }\end{aligned}$
an perhitungan.

\section{Deskripsi}

Subjek mengidentifikasi kesalahan perhitungan dengan menghitung ulang satu persatu jawaban karena waktu mengerjakan masih tersedia.

Subjek memeriksa kecocokan antara yang telah ditemukan dengan apa yang ditanyakan dengan menggunakan konsep perbandingan jika waktu mengerjakan tidak banyak.

\section{P-50 : Yakin dengan jawabannya?}

NK-50 : aaa yakin dehh, karena makin banyak buku makin banyak harganya. Karena kan ini Edo 4 buku tulis Budi 2 buku.

\section{Pemecahan Masalah Berdasarkan Langkah Polya Subjek Kemampuan Sedang}

\section{Memahami Masalah}

\begin{tabular}{ll}
\hline Indikator & Deskripsi \\
\hline $\begin{array}{l}\text { 1. } \\
\text { apwa dapat mengungkapkan }\end{array}$ & Subjek tidak mampu mengungkapkan apa yang diketahui \\
$\begin{array}{l}\text { yang ditanyakan dari soal. } \\
\text { dan apa yang ditanyakan dalam soal }\end{array}$ &
\end{tabular}

DMH-53 : Berarti yang diketahui 30 ekor kambing $=15$ hari sedangkan 5 ekor kambing $=\mathrm{x}$.

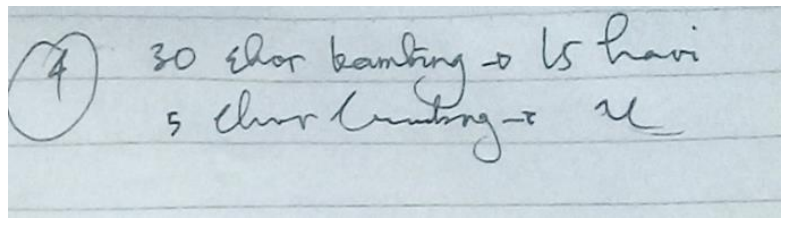

Seharusnya Subjek melakukan pengurangan 30 ekor kambing dengan 5 ekor kambing yang dijual, akan tetapi 
Subjek tidak mampu menggali informasi informasi yang tidak ada dalam soal.

2. Siswa mampu memahami apakah soal termasuk masalah perbandingan senilai atau berbalik nilai
Subjek memahami jenis perbandingan yang digunakan dalam soal dengan bahasa sendiri

\section{Menyusun Rencana Pemecahan Masalah}

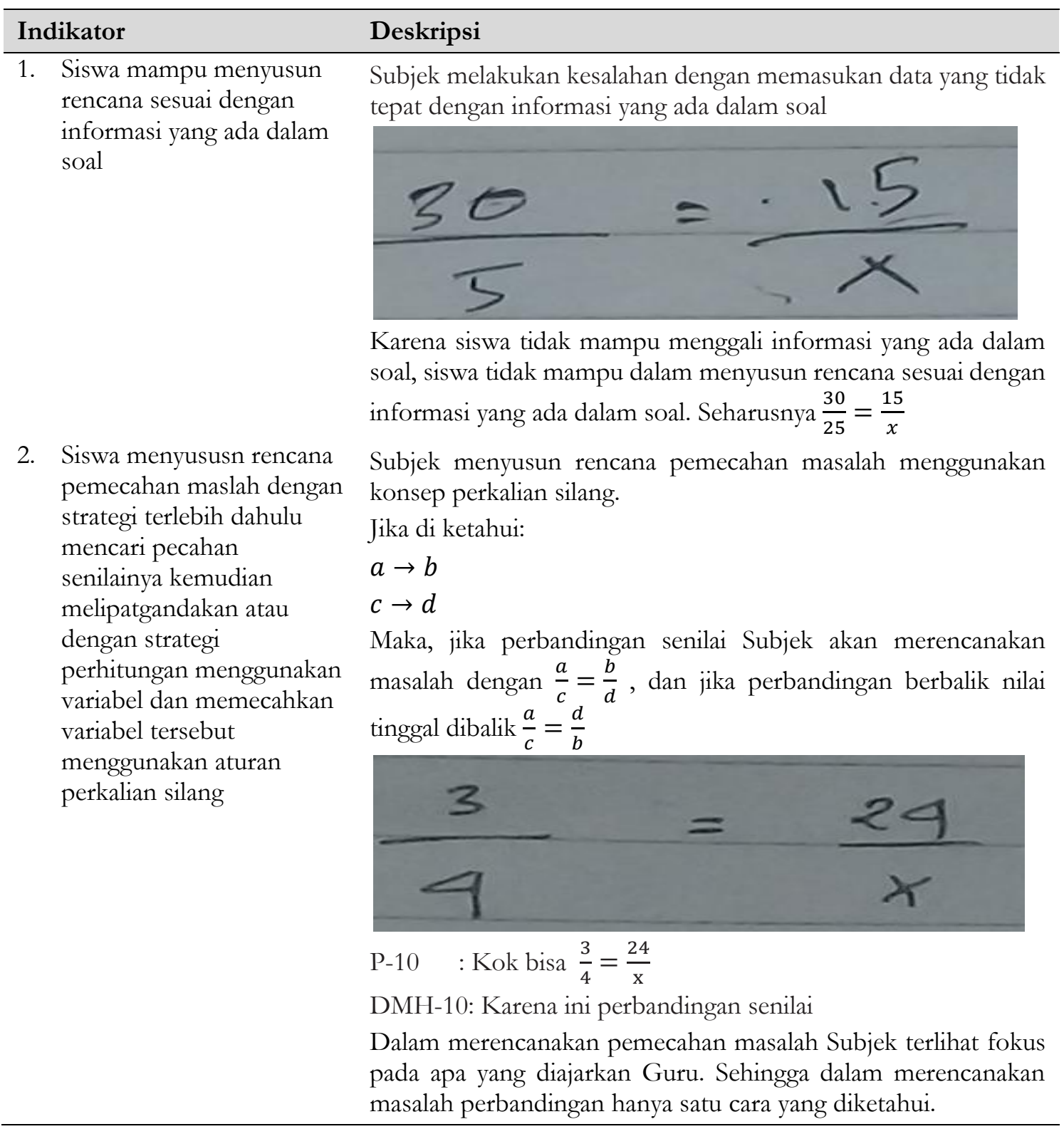




\section{Melaksanakan Rencana Pemecahan Masalah}

\begin{tabular}{l} 
Indikator \\
\hline 1. Siswa mampu melaksanakan \\
rencana pemecahan masalah \\
dengan langkah-langkah yang \\
benar dan perhitungan yang \\
tepat.
\end{tabular}

4. Memeriksa Kembali Solusi yang Diperoleh

\section{Deskripsi}

Subjek melakukan kesalahan dengan tidak mengidentifikasi kesalahan perhitungan atau memeriksa kecocokan antara yang ditemukan dengan apa yang ditanyakan pada soal karena Subjek yakin dan merasa sudah mencoba soal yang serupa.

P-19 :Ok.. Yakin dengan jawabannya
Dek?
DMH-19: InsyaqAllah
P-20: Coba ceritakan ke kakak gimana
bisa yakin dengan jawabannya
DMH-20: Karena udah nyoba ini
P-21 :Apa Adek memeriksa kembali
jawaban setelah selesai mengerjakan soal ini?
DMH-21 : Gak




\section{Pemecahan Masalah Berdasarkan Langkah Polya Subjek Kemampuan Rendah}

\section{Memahami Masalah}

\begin{tabular}{lll}
\hline Indikator & Deskripsi \\
\hline $1 \quad$ Siswa dapat mengungkapkan apa & Subjek tidak bisa mengungkapkan apa yang diketahui \\
$\begin{array}{l}\text { yang diketahui dan apa yang } \\
\text { ditanyakan dari soal. }\end{array}$ & $\begin{array}{l}\text { dan apa yang ditanyakan dengan tepat. } \\
\text { IH-31 : 30 sama dengan 15, } 5 \text { sama dengan a }\end{array}$
\end{tabular}

2 Siswa mampu memahami apakah soal termasuk masalah perbandingan senilai atau berbalik nilai

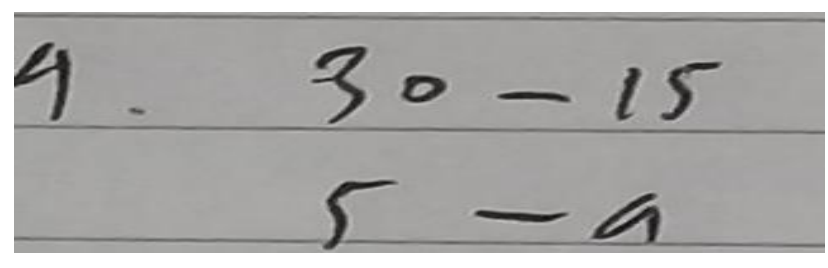

P-32 : 5 Adek dapat dari mana?

IH-32 : Pak Ahmad menjual 5 ekor kambingnya.

Seharusnya Subjek melakukan pengurangan 30 ekor kambing dengan 5 ekor kambing yang dijual, akantetapi Subjek tidak mampu menggali informasi informasi yang tidak ada dalam soal.

Subjek melakukan kesalahan dengan tidak memahami bahwa masalah yang diberikan merupakan perbandingan senilai atau berbalik nilai pada soal nomor 1,2,3 dan 4

P-40 : Ok. Perbandingannya perbandingan apa?

IH-40 : Gak tahu Kak.

\section{Menyusun Rencana Pemecahan Masalah}

\begin{tabular}{l} 
Indikator \\
\hline $\begin{array}{l}\text { Siswa mampu menyusun rencana } \\
\text { sesuai dengan informasi yang ada } \\
\text { dalam soal }\end{array}$
\end{tabular}

\section{Deskripsi}

Subjek melakukan kesalahan dengan memasukan data yang tidak tepat dengan informasi yang ada dalam soal

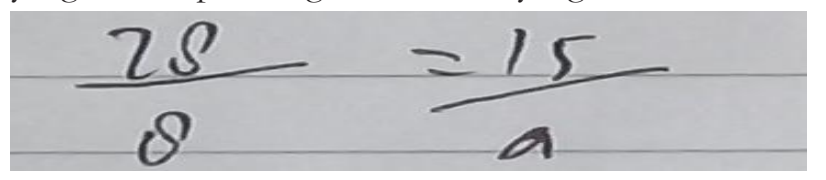

Karena siswa tidak mampu menggali informasi yang ada dalam soal, siswa tidak mampu dalam menyusun rencana sesuai dengan informasi yang ada dalam soal. Seharusnya $\frac{28}{20}=\frac{a}{15}$

2. Siswa menyusun rencana pemecahan maslah dengan strategi terlebih dahulu mencari pecahan senilainya kemudian melipatgandakan atau dengan strategi perhitungan
Pada langkah merencanakan masalah subjek melakukan kesalahan dalam menyusun rencana pemecahan masalah yang seharusnya menggunakan strategi perbandingan berbalik nilai. 
menggunakan variabel dan

memecahkan variabel tersebut

menggunakan aturan perkalian

silang

\section{Melaksanakan Rencana Pemecahan Masalah}

\begin{tabular}{ll}
\hline Indikator & Deskripsi \\
\hline $\begin{array}{l}\text { 1. Siswa mampu melaksanakan } \\
\text { rencana pemecahan masalah } \\
\text { dengan langkah-langkah yang } \\
\text { benar dan perhitungan yang } \\
\text { tepat. }\end{array}$ & $\begin{array}{l}\text { Pada langkah melaksanakan rencana pemecahan masalah } \\
\text { Subjek melakukan kesalahan perhitungan }\end{array}$ \\
& $\begin{array}{l}\text { Subjek melakukan perhitungan yang tidak tepat karena } \\
\text { kemampuan aritmatika seperti perkalian, pembagian, } \\
\text { penjumlahan dan pengurangan belum dikuasai. }\end{array}$
\end{tabular}

\section{Memeriksa Kembali Solusi yang Diperoleh}

\begin{tabular}{ll}
\hline Indikator & Deskripsi \\
\hline $\begin{array}{l}\text { 1. Siswa mengidentifikasi kesalahan } \\
\text { perhitungan. }\end{array}$ & $\begin{array}{l}\text { subjek melakukan kesalahan dengan tidak } \\
\text { mengidentifikasi kesalahan perhitungan atau memeriksa } \\
\text { kecocokan antara yang ditemukan dengan apa yang } \\
\text { ditanyakan. }\end{array}$ \\
& \\
P-11 : Oke, yakin dengan jawabannya? & \\
IH-11 : Yakin Kak \\
P-12 : Tadi jawabannya diperiksa ulang? \\
IH-12 : Ndaq pernah Kak \\
P-13 : Kenapa gak diperiksa ulang? Mungkin \\
jawabannya Adek salah. \\
IH-13 : Benar dah itu Kak
\end{tabular}

Berdasarkan hasil penelitian, siswa berkemampuan matematika tinggi tidak melakukan kesalahan dalam memahami masalah. Siswa berkemampuan tinggi mengungkapkan dengan jelas apa yang diketahui dan ditanyakan oleh soal dan mengetahui jenis perbandingan yang digunakan. Hal ini dikarenakan ketika siswa dihadapkan pada suatu bentuk perbandingan, ternyata siswa mengacu pada soal yang diberikan (Nugraha, Sujadi, \& Pangadi, 2016). Untuk dapat memahami masalah dengan baik, siswa berkemampuan tinggi menuliskan apa yang diketahui dalam bentuk tabel. Pada beberapa kasus siswa dengan kemampuan tinggi

Faseha, at.al (2021), Analisis kesalahan siswa dalam memecahkan masalah........| 40-54 |

| Vol. 01, No. 01, Maret 2021| h. 51 
meringkas soal sehingga siswa mampu melihat dengan jelas informasi apa yang diketahui dan ditanyakan dalam soal. Hal yang dilakukan siswa sesuai dengan pendapat Polya (dalam Reksy Meilando, dkk 2017:214) bahwa siswa harus melihat dengan jelas apa saja yang diperlukan dalam memahami masalah dengan baik.

Siswa berkemampuan sedang dan rendah berdasarkan analisis data pertama dan kedua melakukan kesalahan memahami masalah. Siswa tidak mampu mengungkapkan apa yang diketahui dan apa yang ditanyakan dalam soal. Menurut analisis peneliti, siswa tidak mampu mengungkapkan apa yang diketahui dan ditanyakan dalam soal karena kemampuan membaca soal siswa kurang sehingga tidak dapat menemukan kata kunci yang ada pada soal. Kurangnya kemampuan membaca akan mengakibatkan kesalahan dalam menyelesaikan masalah. Hal tersebut senada dengan pendapat Newman yang mengkategorikan sebagai kesalahan membaca. Menurut Newman (dalam Aninditya, dkk 2017:454) kesalahan membaca terjadi karena siswa salah dalam membaca soal sehingga saat mengerjakan soal siswa tidak dapat menggunakan informasi yang terdapat dalam soal dan membuat jawaban siswa tidak sesuai dengan maksud soal. Siswa dengan kemampuan matematika rendah juga melakukan kesalahan memahami masalah yakni, siswa tidak mampu memahami bahwa masalah yang diberikan merupakan perbandingan senilai dan perbandingan berbalik nilai. Berdasarkan analisis peneliti hal tersebut terjadi karena kemampuan konseptual siswa kurang.

Selanjutnya pada langkah merencanakan pemecahan masalah, siswa berkemampuan matematika tinggi sedang dan rendah memiliki rencana penyelesaian. Rencana yang digunakan siswa berkemampuan tinggi sedang dan rendah dengan strategi perhitungan menggunakan variabel dan memecahkan variabel tersebut menggunakan aturan perkalian silang. Pada beberapa kasus siswa berkemampuan tinggi merencanakan masalah dengan strategi terlebih dahulu mencari pecahan senilainya kemudian melipatgandakan. Rencana yang dibuat untuk membantu keberhasilan dalam menyelesaiakan masalah. Hal ini sesuai dengan pendapat Polya (dalam Reksy Meilando, dkk 2017:227) bahwa keberhasilan utama menyelesaikan masalah bergantung bagaimana rencana yang dibuat.

Siswa dengan kemampuan sedang dan rendah melakukan kesalahan dalam merencanakan masalah siswa menyusun strategi dengan menggunakan variable dan memecahkan variabel tersebut menggunakan aturan perkalian silang, akan tetapi siswa memasukan data yang tidak tepat dengan informasi yang ada dalam soal. Siswa dengan kemampuan rendah salah dalam merencanakan strategi pemecahan masalah, siswa menggunakan strategi perbandingan senilai yang seharusnya menggunakan perbandingan berbalik nilai. Dalam merencanakan masalah siswa hanya mengetahui satu cara dan cara yang digunakan hanya seperti yang diajarkan gurunya.

Pada tahap melaksanakan rencana pemecahan masalah, siswa berkemampuan matematika tinggi tidak mengalami kesalahan. Siswa dengan kemampuan sedang dan rendah mengalami kesalahan dalam melaksanakan rencana. Siswa tidak mampu melaksanakan rencana pemecahan masalah dengan langkah-langkah yang benar dan perhitungan yang tepat. Berdasarkan hasil wawancara dengan siswa bahwa kemampuan awal aritmatika yakni operasi aritmatika berupa perkalian dan pembagian belum sepenuhnya dikuasai. Dalam melaksanakan rencana pemecahan masalah kemampuan awal aritmatika yang diproleh siswa | 40-54 | 
sebelumnya sangat mempengaruhi. Sesuai dengan yang dikemukakan oleh Mubarik (dalam Reksy Meilando, dkk 2017:227) bahwa untuk menyelesaikan masalah, seseorang harus menguasai hal-hal yang telah dipelajari sebelumnya dan mengunakannya dalam situasi yang baru.

Tahapan memeriksa kembali solusi yang diperoleh siswa berkemampuan matematika tinggi memeriksa kembali penyelesaiannya dengan cara memeriksa kecocokan antara yang telah ditemukan dengan apa yang ditanyakan. Hal ini sesuai dengan penelitian Resky Meilando, dkk (2017:228) bahwa siswa dengan kemampuan tinggi memeriksa kembali penyelesaiannya dengan cara perhitungan ulang. Siswa berkemampuan sedang melakukan kesalahan dengan tidak memeriksa solusi yg diperoleh. Siswa berkemampuan sedang dan rendah tidak memeriksa kembali solusi yang diperoleh karena sudah yakin dengan jawabannya. Adapun temuan lainnya adalah terdapat hal yg menarik yakni rata-rata siswa melakukan kesalahan dalam memecahkan masalah perbandingan berbalik nilai. Hal tersebut terjadi karena pemahaman konsep terhadap materi perbandingan berbalik nilai masih kurang. Dalam menyelesaikan masalah perbandingan siswa lebih fokus pada materi yang pertama diajarkan yakni materi perbandingan senilai, sehingga dalam merencanakan masalah perbandingan berbalik nilai siswa menggunakan rencana pemecahan masalah perbandingan senilai.

\section{Kesimpulan}

Dari data yang diperoleh dan analisis data yang telah dilakukan, dapat disimpulkan bahwa jenis kesalahan yang dilakukan siswa dalam memecahkan masalah perbandingan adalah sebagai berikut: (1) Pada langkah memahami masalah siswa tidak dapat menggali informasi penting yang tidak ada dalam soal sehingga siswa salah dalam mengungkapkan apa yang diketahui dan yang ditanyakan. Kemampuan konseptual siswa kurang dalam menyelesaikan masalah perbandingan sehingga siswa salah dalam membedakan perbandingan senilai dan berbalik nilai; (2) Pada langkah merencanakan masalah, siswa tidak dapat merencanakan masalah sesuai dengan informasi yang ada dalam soal dan siswa merencanakan pemecahan masalah menggunakan strategi perbandingan senilai yang seharusnya menggunakan perbandingan berbalik nilai; (3) Pada aspek melaksanakan rencana pemecahan masalah, karena kemampuan aritmatika dasar siswa kurang siswa tidak dapat menghitung dengan perhitungan yang tepat sehingga langkah-langkah yang di buat menjadi kurang tepat; (4) Pada langkah memeriksa kembali solusi yang diperoleh siswa tidak memeriksa kembali solusi yang diperoleh karena yakin dengan jawabannya

\section{Referensi}

Dwi, Ananditya Candra Buana Putra, dkk, "Analisis Kesalahan Siswa Dalam Memecahkan Permasalahan yang Berkaitan dengan Persamaan Garis Lurus Kelas VIII SMP”, Seminar Nasional Matematika dan Pendidikan Matematika (2 ${ }^{\text {nd }}$ SENATIK) Program Studi | 40-54| 
Pendidikan Matematika FP MIPATI- Universitas PGRI Semarang, Semarang, 12 Agustus 2017. Hlm. 454.

Charitas, Rully, "Permainan Tepuk Bergilir Yang Berorientasi Konstuktivisme Dalam Pembelajaran Konsep Kpk Siswa Kelas IV Di SDN 21 Palembang”, Jurnal Pendidikan Matematika, Vol. 4.Nomor 2, Desember 2010, hal. 61

Emzir, Metodologi Penelitian Kualitatif Analisis Data, (Jakarta: Rajawali Pers, 2010), hlm. 20

Meilando, Reksy, dkk," Profil Pemecahan Masalah Aritmatika Sosial Siswa Kelas VIII SMP Labschool Untad Palu Ditinjau Dari Kemampuan Matematika", Jumal Elektronik Pendidikan Matematika Tadulako, Vol. 5 , Nomor 2, Desember 2017, hlm. 214

Nugraha, Y., Sujadi, I., \& Pangadi, P. (2016). Penalaran Proporsional Siswa Kelas VII. Beta Jurnal Tadris Matematika, 9(1), 34. https://doi.org/10.20414/betajtm.v9i1.2

Rahmawati, dkk, "Kertas Berpetak Pada Pembelajaran Perbandingan Senilai", Elemen, Vol. 2, Nomor 2, Juli 2016, hal. 116-126.

Utari Rahma Siska, dkk, Konteks Kebudayaan Palembang untuk Mendukung Kemampuan Bernalar Siswa SMP pada Materi Perbandingan. Jurnal Didaktik Matematika, Vol .2, Nomor 2, hal.27-37.

Polya, How To Solve It, New Jersey: Princeton University Press, 1973.

Wahyu Henky Irawan, et. al. Pengantar Teori Bilangan, (Malang: UIN-Maliki Press, 2014), hlm. 201 